\section{Educational computer games in geography}

Wojciech Pokojski

Summary:

DOI: $10.24131 / 3247.170108$

The Internet provide access to interactive websites and applications on-line for learning.

The article presents an overview of the didactic games in a field of geographical education available mainly in the form of websites and online applications enabling interactive learning. This article contain evaluation of these games.

Key words: didactic games, geography, Street View

received: 19.10.2016; accepted: 22.12.2016; published: 18.04.2017

Wojciech Pokojski, PhD: Faculty of Geography and Regional Studies, University of Warsaw wpokojski@uw.edu.pl

\section{Introduction}

At the time of functioning of the information society, it is the duty of the teacher to use various techniques supporting the learning process in the classroom. The development of the Internet and computer techniques has contributed to many ingenious applications and programmes dedicated to conveying information and acquiring knowledge. A teacher willing to enrich his or her toolkit and to make his or her students' learning more diverse and reaching for such tools should be able to first evaluate them critically, and then to recommend the selected, best ones to the students. Through identification of learning assisting applications and programmes, a teacher may build the new learning environment, as described by M.M. Sysła (2009), for himself or herself and for the students through the creation of conditions for acquiring skills: "seeking, ordering and using information from various sources and effective use of the information technologies". According to Z Osiński (2009), the use of information technologies in teaching is aimed at obtaining by students key competences to prepare young people for successful functioning in the reality of information society.

Skilfully introduced into a series of lessons, educational games enable development of memory, perceptiveness, attention, logical associating and reasoning skills (Nodzyńska, 2011), they teach perception of rules and are an element that improves the attractiveness of classroom activities (Czepiżak, Wądołowski). According to Kisiel (2011), introduction of educational games into the teaching process enriches curricula not only with multimedia elements, but also interactive ones, which should lead to a more attractive and effective instructional process.

The first computer programmes dedicated to teaching geography emerged in the 1980 s, electronic atlases became common in the 1990s (Pliszka, 1997), which were then superseded along with the development of the Internet with interactive maps, geoportals and virtual globes that belonged to a new subcategory of GIS - called webGIS (Pokojski, Pokojska, 2012). The possibility to use virtual globes in school teaching were presented in one of earlier works (Pokojska, Pokojski, 2015).

The Internet is an element of everyday activity of teenagers, $86.2 \%$ of them use the web on a daily basis, while $43.2 \%$ of young people are constantly online
(Lange, Osiecki, 2014). As results from the report of the Education Development Centre, as many as $76 \%$ of young web users use the Internet to do their homework and seek information. Contemporary students often start looking for information by means of the computer, so it is worthwhile to show students online resources that will facilitate studying geography and make it more diversified. In the opinion of Pliszka (1997), this task should be fulfilled above all by the teacher and the application of a computer programme for teaching purposes should bring the expected result in the form of built-up or consolidation of knowledge, for the "computer-assisted education" defined by J.M. Morbitzer (2007) to be common end efficient also in the area of teaching geography and nature.

The use of computer games may have a very positive impact on motivation for learning, which is testified to by studies conducted in Greece (Papastergiou, 2009) among secondary school students; some of the students used games in the educational process, while others studied in the traditional way. Those who used games obtained better results at the test administered at the end of the experiment. Similar studies conducted in Turkey on a group of primary school students showed better motivation for studying and, consequently, better outcomes obtained by students who used a computer game concerning continents and countries of the world with respect to the other students (Hakan et al. 2009). Similar conclusions were drawn during an experimental study carried out in Canada (Lotherington, Ronda, 2009).

\section{Educational games and their role in geography teaching}

Some educational games that function as computer software are available at web portals that provide access 
to installation files of computer programmes and applications. At the dobreprogramy.pl portal, in the category Geography, one can find installation files of several computer games, including those described below, Seterra and World Geography. Installation files, as well as games, available previously in the form of computer programmes transformed into online applications, can be found through web search engines by entering an appropriate query.

One of the main educational goals in the primary school core curriculum is to identify features on the map, countries, mountain ranges, places where specific landscape types dominate, etc. ${ }^{1}$ Educational games may also be used to teach geography at the lower secondary level, as the connections and spatial relations between human and the geographical environment are the foundation of education at that educational level. One of the goals of education at the third educational level in the subject of Geography is the ability to use the map to locate the most important geographical features in the world and in Poland, and exercises and tasks with maps should form a basic and integral part of most lessons of Geography (Core Curriculum...) $)^{2}$. Educational games combine education with entertainment, they give the possibility to convey knowledge in a more interesting and easily absorbable way. Among other things, they enable broadening the knowledge of the location of countries, cities, expanding the ability to recognise landscapes and finding out spatial relations between landscape features. In addition, through the limited time for task completion, the "teach" making decisions and show the effects of the decisions made, they enable simulation of behaviour in the real world. Thanks to the

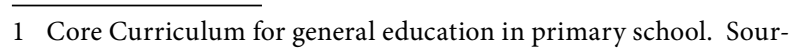
ce: https://men.gov.pl/wp-content/uploads/2014/08/zalacznik_2. pdf

2 Core Curriculum of geography, 3rd stage of education. Source: https://men.gov.pl/wp-content/uploads/2011/02/5e.pdf. use of educational games, their participants can develop the so-called spatial reasoning skill and learn to orientate themselves in the field.

Below, there is a list of a few popular online games and applications in the area of geography, which can, in a simple and intuitive way, facilitate learning geography, especially mastering the spatial location of places and features on the map. They can be successfully used and presented during lessons of nature in the primary school, when students learn how to use the map. Some of them, due to the presented issues, may be used in geography teaching in lower secondary schools. Due to different scope of the presented games and applications, the subjective ranking (in the table) is only aimed at helping the teacher and students to choose those that are the most useful, instructive and helpful in consolidation of acquired knowledge. The overview includes games that do not require a fast microchip or too high IT skills. The first versions of some of the selected games were developed almost 20 years age, so they may discourage a contemporary web user with their simplicity of execution, poor graphic design and lack of animations. However, that also makes them simple, intuitive and often, despite the passage of time since their origin, still attractive. The overview does not include city games and games related to Geographical Information System (GIS), which use recording of the route covered or location of the place obtained through the GPS.

\begin{tabular}{|c|c|c|c|c|}
\hline $\begin{array}{l}\text { Name of the } \\
\text { game }\end{array}$ & Type & Downloaded from & Scope and usefulness of the game & Rating \\
\hline Geoquessr & Online application & http://geoguessr.com & $\begin{array}{l}\text { Recognising places where photos were } \\
\text { taken, pointing to the locations on the map, } \\
\text { relations nature - human - economy }\end{array}$ & 5 \\
\hline $\begin{array}{l}\text { World Geography } \\
\text { (Geografia świata) }\end{array}$ & Computer programme & http://dobreprogramy.pl & $\begin{array}{l}\text { Work with the map, verifying knowledge, } \\
\text { puzzles - setting up a map }\end{array}$ & 5 \\
\hline Seterra & $\begin{array}{l}\text { Computer programme } \\
\text { and online application }\end{array}$ & $\begin{array}{l}\text { http://dobreprogramy.pl } \\
\text { http://online.seterra.net/pl }\end{array}$ & Work with the map & 5 \\
\hline $\begin{array}{l}\text { Geography } \\
\text { Games (Gry geo- } \\
\text { graficzne) }\end{array}$ & Online application & http://www.gry-geograficzne.pl/ & $\begin{array}{l}\text { Work with the map, a selection of problems, } \\
\text { indicating the correct element on a graph } \\
\text { or diagram }\end{array}$ & 4 \\
\hline Enigeo & Computer programme & http://www.enigeo.org/pl/ & Work with the map & 4 \\
\hline $\begin{array}{l}\text { Geostrefa - geog- } \\
\text { raphy games }\end{array}$ & Online application & www.geostrefa.pl & $\begin{array}{l}\text { Work with the map, puzzle - setting up } \\
\text { a map }\end{array}$ & 3 \\
\hline $\begin{array}{l}\text { Geography - edu- } \\
\text { cational games }\end{array}$ & Online application & http://geografia-gry.strefa.pl/ & crosswords, a selection of tasks, quizzes & 3 \\
\hline Toporopa & Online application & http://www.toporopa.eu/pl/ & Work with the map & 3 \\
\hline
\end{tabular}

Table 1. List of described games and applications

Source: own study. 


\section{Characterisation of the selected games}

Geoguessr.com

The commonly known Google Maps are a tool that facilitates finding features on the map. The service is classified as a geobrowser (Rzeszewski, Jasiewicz, 2009), its basic function is geolocation, consisting in finding the location of a feature. Not all Google Maps users know about the possibility to look for places with known geographic coordinates through entering the coordinates of the place sought, expressed in degrees, minutes and seconds of latitude and longitude. From the point of view of combining education with fun, the Street View service should be noted. It covers panoramic photos, taken with the use of a special recording tool that makes it possible to capture a panorama of 360 degrees horizontally (Pokojska, Pokojski 2012). Panoramic images from Street View, an educational game called Geoguessr.com was developed.
It consists in guessing the place where panoramic photos were taken and indicating that place on the world map (Fig. 1). Before the game, it is possible to choose either panoramas from the whole world, or limit the area where they are taken to continents, countries or cities, or thematic sets, such as stadiums of Europe. After indication of the place where the photo was taken, the application "calculates" the error in distance with respect to the actual place of taking and awards a number of points reversely proportional to the obtained error.

After indicating 5 places of taking a panorama, there is a summary identifying the errors made. The seemingly easy task requires the player to use his or her knowledge about vegetation formations and their zonal distribution, knowledge of issues related to the type of agriculture, landscape variation, development of road network and settlements, knowledge of foreign languages (a place may be located easier thanks to road signs), location of cities or names of rivers (found on road signs). Other useful aspects include knowledge about left-hand or right-hand traffic, physical and cultural anthropology (people in the street), popularity of car makes in specific countries and many other aspects of human life. The application is extremely valuable, as it enables combination and verification of knowledge from many areas of science and is recommended to everyone, especially secondary school students. Logging onto the game makes it possible to enter into rivalry with several players, and in the paid version, each user may choose interesting places and prepare the game for other participants. The game is so "engrossing," that players should be warned of the possibility of addiction.

\section{World Geography}

The World Geography programme, which needs to be installed, can be downloaded free of charge from the

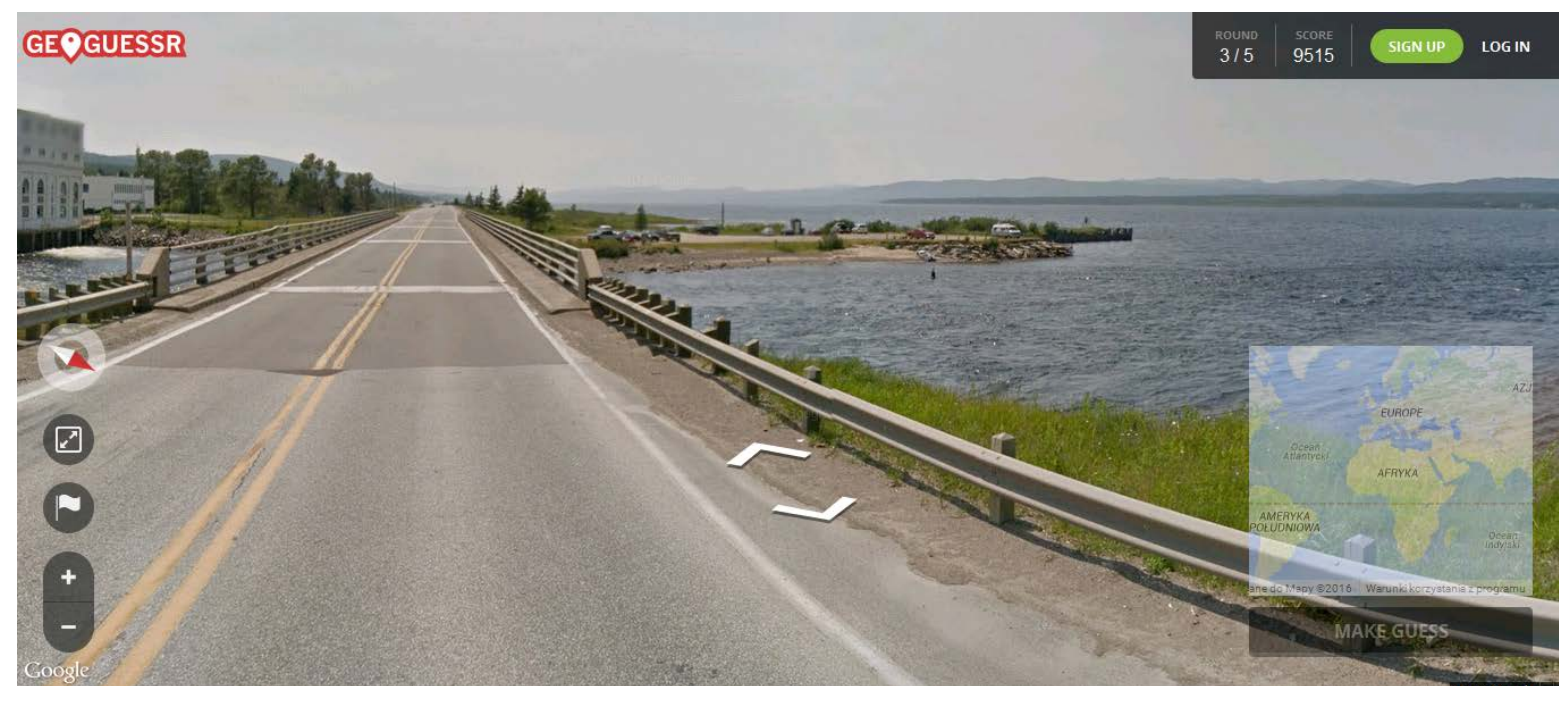

Fig. 1. Geoguessr.com screenshot

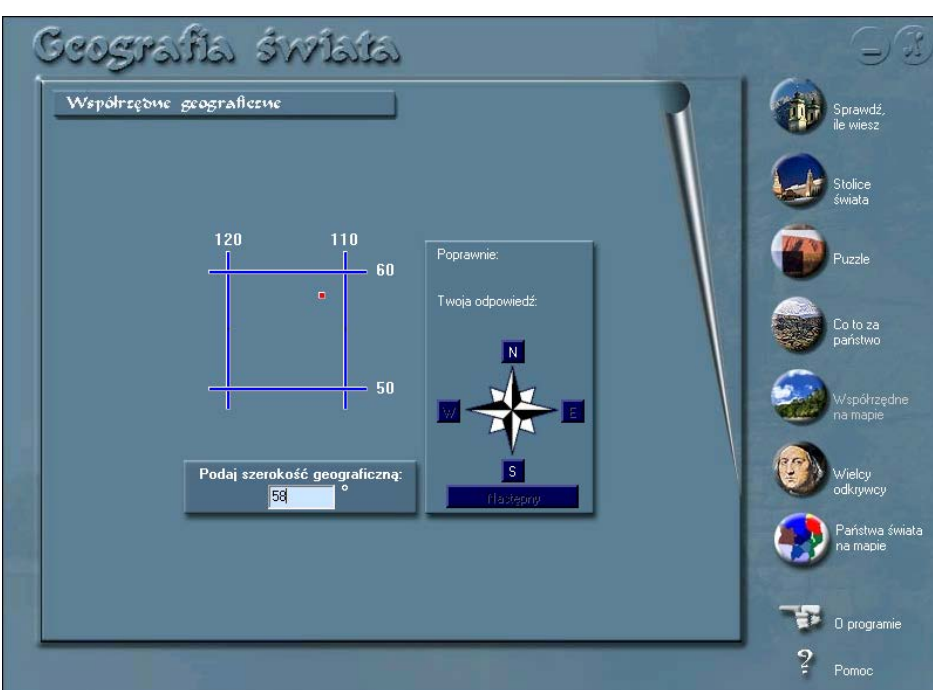

Fig. 2. Window of the Wold Geography programme with the Map Coordinates module launched. 
dobreprogramy. $\mathrm{pl}^{3}$ website. The programme enables learning the basic and selected problems of geography, its functionality goes beyond simply asking about the location of features on a map. One of the options is puz$z l e$, beside which there are modules like Map Coordinates and Great Explorers (Fig.2). As regards the Check what you Know module, it is a test of geographical knowledge, in which the right answer must be checked.

The game is simple and intuitive, and its popularity is testified to by the data - since 2009 , it has been downloaded from the portal dobreprogramy.pl 75,000 times and it has been highly rated by the website users. The rating of the game was 5 points and it may be recommended to students of both primary and secondary schools.

\section{Seterra}

Seterra ${ }^{4}$ is an educational game that contains more than 100 quizzes, and whose major slogan is "Learn geography while having fun". In the game, one should indicate the location of continents, countries, capital cities and larger cities, as well as recognise the flags of specific countries. The territorial scope of the programme is mostly limited to Europe and North America. It is worth pointing out that Seterra has been developed since 1998 and it is available in 30 language versions. The programme has been downloaded from the website dobreprogramy.pl (the Polish version) around 20,000 times and has been very highly rated. For those who prefer to use an online application, there is also the English language version online. ${ }^{5}$ It contains the same modules as the installation version. The use of other language

3 Geografia świata: http://www.dobreprogramy.pl/Geografia-swiata,Program,Windows,11633.html

4 Seterra - installation package: http://www.dobreprogramy.pl/ Seterra,Program,Windows, 11839. html

5 Review of Settera programme on dobreporgramy.pl http://online. seterra.net/pl versions of the game (including the English one) enables "incidental" learning of geographical names in foreign languages, the game may be used in the classroom also by foreign language teachers.

It is worthwhile to quote one of the reviews posted at the dobreprogramy.pl website by a person using the nick 80mentor:

At the start, I would like to recommend that very good programme for learning geography. Seterra is an excellent almanac of all kinds of quizzes, thanks to which we can check our knowledge of the location of continents, countries, cities, islands, mountains, flags, etc. The programme is clear in its form and all quizzes are visible in the main window, they are also divided by topic, which determines the content of the questions to be solved against the clock, the highest score table is available in the background, which motivates to improve one's results. Beyond doubt, the programme is an invaluable help for school and university students, as well as all people passionate about geography. I recommend it. ${ }^{6}$

The author of the article fully concurs with that opinion. It is worth noting that, beside guessing the location of cities, countries, provinces (the administrative division for Poland according to voivodeships), we can also select an option with the selection location on the map of the greatest islands, volcanoes, oceans, seas and lakes. After completion of a session, the online player can publish his or her result through the social networking service Facebook.

\section{Geography Games}

Geography Games - play and learn about the world is a set of games and tasks consisting in indication of the right item, most often a country, on the map (Fig. 3). This part of the game can be recommended to primary

\footnotetext{
6 http://www.dobreprogramy.pl/Seterra,Program,Windows,11839. html

7 http://www.gry-geograficzne.pl/
}

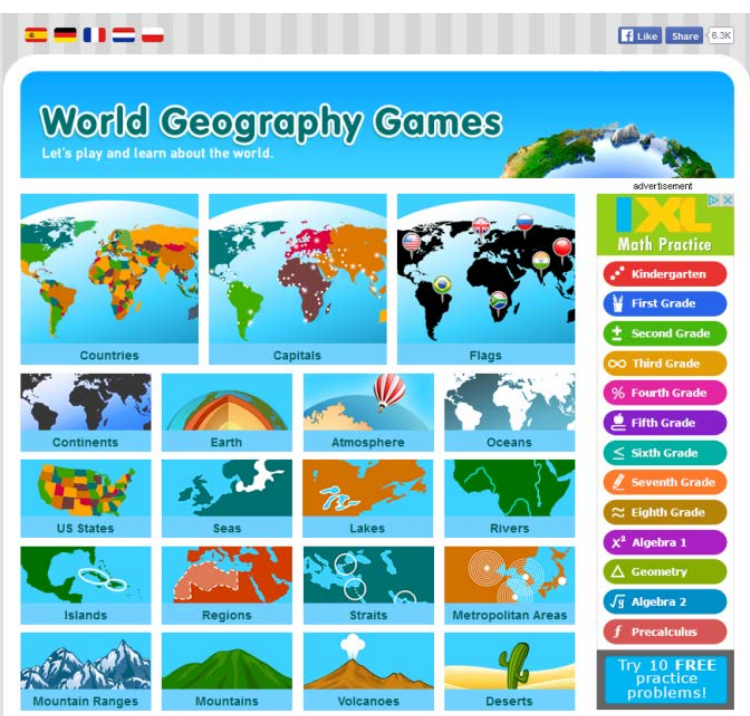

Fig. 3. List of games on the website http://worldgeography-games.com (the Polish version is available at gry-geograficzne.pl)

school students to help them in learning the location of specific countries. Lower secondary school students can make use of that part of the game which consists in verification of knowledge through selecting the correct reply option from the list or indication of the right element on a graph or diagram. For instance, the Earth game enables consolidation of knowledge about the geologic layers of Earth (Fig. 4).

The application is available in several language versions, and it has been developed, just like Toporopa, by EastDock Media from the Netherlands. Quizzes concern almost all countries of the world, the information comes from Wikipedia and CIA World Factbook, while information concerning volcanoes come from The Global Volcanism Program. 


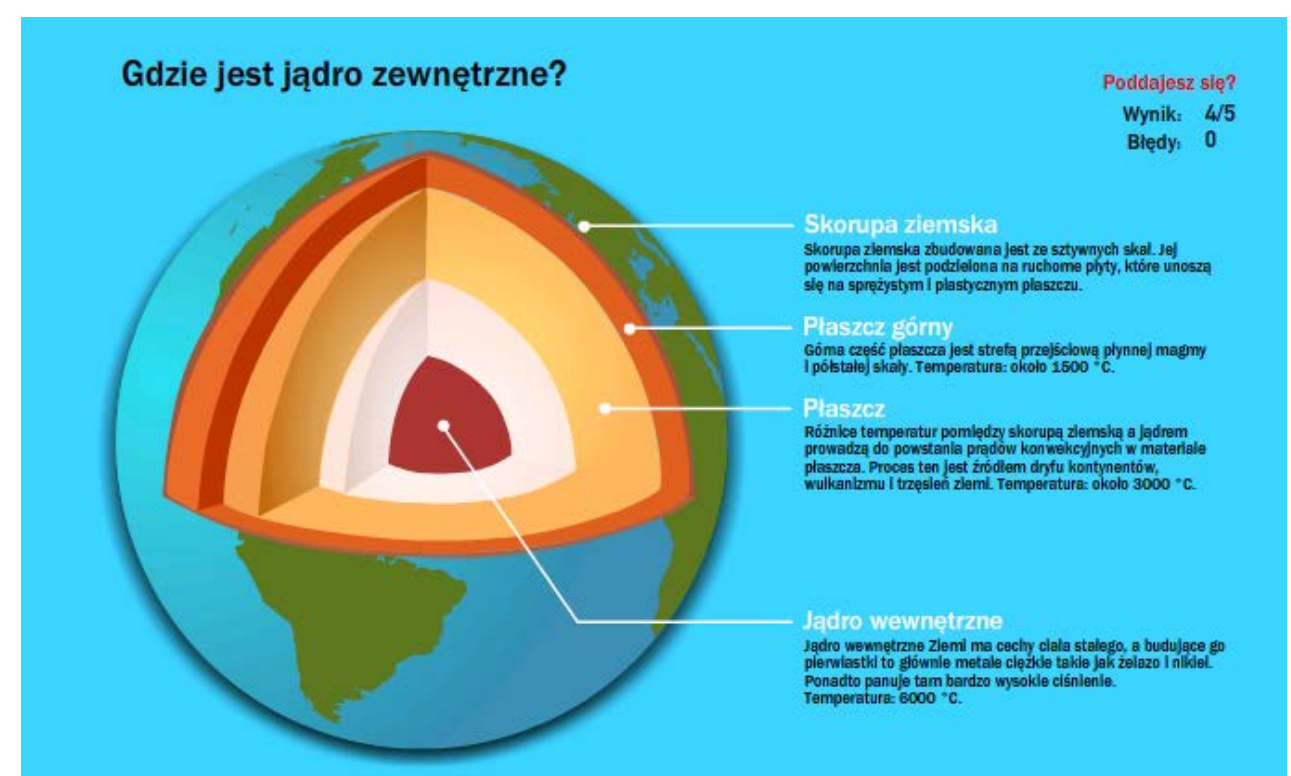

Fig. 4. The Earth game launched at gry-geograficzne.pl

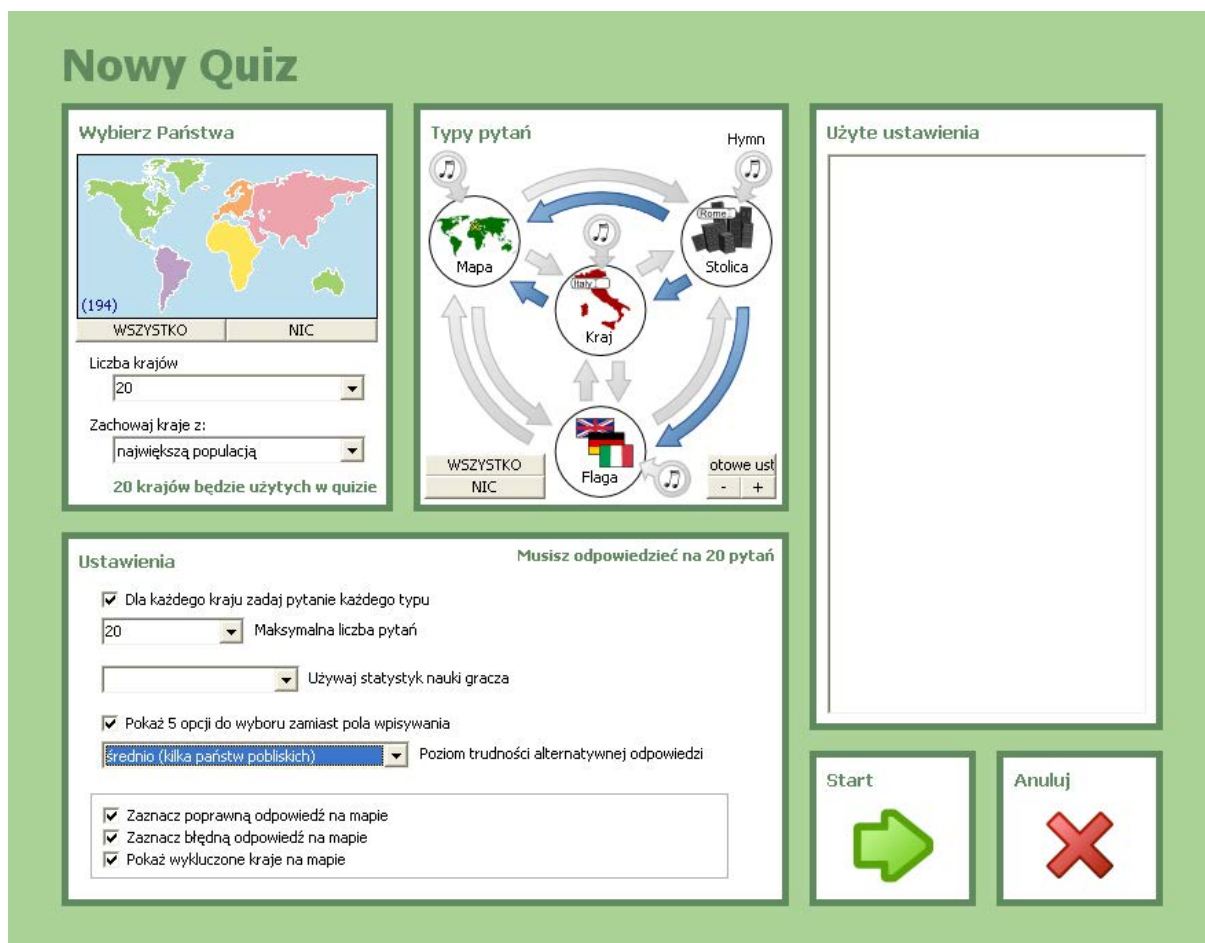

Fig. 5. Configuration panel of Enigeo

\section{Enigeo}

Enigeo $^{8}$ contains two modules: the quiz mode and the exploration mode. The game is available in 15 language versions, including Polish. Questions concern names of countries, capital cities, and their location on the map, as well as flags and national anthems (Fig. 5). The game must be downloaded and installed, but its use is not complicated. Besides, interacting with the game forces the user to choose the difficulty level and scope of questions. The game can help students of grades 4-6 of primary school in consolidation of knowledge about some countries.

8 http://www.enigeo.org/pl/

\section{Geography Puzzles}

On the geostrefa.pl ${ }^{9}$ website, which contains materials for teaching geography intended for students and teachers, one of the tabs of Geography Games contains Geography Puzzles. Using the games requires registration and logging on. The seemingly easy game makes it possible, unlike most games described in this article, rather than to indicate the location on the map, to assemble puzzles - a physical map of Poland, or an outline map of Poland. The puzzles were prepared in three versions: easy, difficult and very difficult. The game "teaches" a very important element of geography education

9 http://www.geostrefa.pl/puzzle_z_geografii,12.html
- spatial relations between geographical features. Due to different difficulty levels, it can be recommended to students of primary and lower secondary schools.

\section{GEOGRAPHY - Educational Games}

On the GEOGRAPHY - Educational Games ${ }^{10}$ website, there are available crosswords, matching games, and selection tasks concerning general issues (astronomy, lithosphere) and dedicated to specific continents, in categories like flags, lakes, rivers, capital cities. For the territory of Poland, there were placed tasks concerning

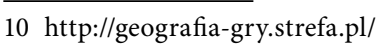


symbols of national parks and rivers. This is the second of the described games which does not use maps.

\section{Toporopa}

Toporopa $a^{11}$ is the title of a website containing educational games that concern European countries, regions, cities, flags, monarchies, mountains, waters, and other issues. Simplifying slightly, one may say that it is a version of Geography Games that contains questions about Europe. The Polish language version is one of 15 language versions. The use of the game is very easy and intuitive. Besides questions concerning indication on the map of geographical features, such as straits, lakes, countries, metropolis, attention should be paid to quizzes concerning European Monarchies and European Battles. In the ranking, the game received the lowest score, yet it may be recommended for nature lessons of primary school students.

\section{The use of games in nature and geography \\ lessons}

Educational games cannot substitute material developed in the form of a textbook, an atlas or exercise book. However, they may be a supplement that enables reviewing material related to location of features or enabling checking knowledge in the lessons of nature and geography.

The presented games may be used as support of the teaching process; Geography puzzles can be used during lessons on our homeland and other European countries to a good effect. The game may also be used during lessons dedicated to contour map and band-like arrangement topographic zones in Poland, when its part consisting in arrangement of the Physical Map of Poland can be utilised.

\footnotetext{
$\overline{11 \mathrm{http}: / / w w w . t o p o r o p a . e u / p l /}$
}

As regards the game Seterra, it may be used as a teaching aid during nature lessons in grade 5 to teach the location of countries of the European Union. Using the Google Maps application and virtual panoramas from the Street View service, the teacher can indicate and discuss typical landscapes of Poland in the classroom, illustrating them with appropriate examples of lowland, highland and mountain landscapes.

In grade 6 , a section of the curriculum dedicated to lands and oceans is taught in nature lessons, with indicating the location of continents and oceans of the world map as one of the learning objectives. The following games can be used to consolidate the obtained knowledge: Geography games - quizzes Continents, Oceans, Seas, Seterra, World geography, Enigeo.

During lessons about the landscapes of the Earth, the Street View application and the game Geogessr can be helpful - while using them, the teacher may indicate and discuss typical landscapes, characteristic for specific climatic zones. Finding characteristic landscapes with the use of the Street View application may be a tool used by the student while preparing a homework assignment, an essay or a presentation.

While discussing the rotation and revolution of Earth, the animations found at the website Interactive Sites for Education ${ }^{12}$ may be a useful supplementation of the textbook. For instance, the Earth's orbit ${ }^{13}$ animation may facilitate understanding of the principles and consequences of Earth's revolution around the Sun and rotation around its axis.

Educational games may also be used during geography lessons in lower secondary schools.

Most of the discussed games can be used to consolidate knowledge concerning the geographical position and the location of points and areas on the map, in

$12 \mathrm{http} / /$ interactivesites.weebly.com/earth-moon-and-sun.html $13 \mathrm{http} / / /$ www.ictgames.com/dayNight/index.html which context the coordinates module in the World Geography game is the most worthy of recommendation.

To consolidate the knowledge of the political division of Europe, one may use the geographical games of Seterra, Toporopa and Enigeo. During lessons dedicated to the review of geographical regions of Poland, the teacher can, using the Street View module in the Google Maps application or the Geogessr game, present characteristic landscapes for specific regions. The games may be used not only while working with the map, but the choice of tabs on the Geographical games enables learning and consolidation of knowledge about the structure of the atmosphere and the Earth internal structure (the Atmosphere and Earth tabs).

\section{Conclusion}

Consolidation of knowledge of the location of a place on the map, quizzes and tasks available in computer games enable combination of learning with fun, and most of all develop spatial imagination. Some of the games are a few or over a dozen years old and may discourage teenagers with unattractive graphic design, but they are simple, intuitive and do not require a fast Internet connection in the case of online games.

A teacher who uses the online resources may make students more interested in geography, as well as convey knowledge more quickly. Thanks to it, young people will be better prepared for productive functioning in the information society and they will improve the self-development skills (Pokojski, 2012). The subjective assessment is only aimed at pointing out to teachers and students of those games and applications, which, according to the author, are useful in consolidation of geographical knowledge (received a score of 5). The games presented in the article have been highly rated as a teaching aid by teachers - students at postgraduate 
studies in the area of teaching geography and nature organised by the Department of Geography and Regional Studies of Warsaw University.

On the Internet, there are numerous lists of games intended for nature education, and due to the English language versions also for teaching the English language in primary schools. The list presented by the National Geographic ${ }^{14}$ is valuable. At the beginning of the presented list, beside educational qualities, their role in development of the decision-making skills was highlighted. Educational games are also made available by environmental institutions. On the website of the American agency NOOA (National Oceanic and Atmospheric Administration $)^{15}$ a portal of games and interactive activities concerning oceans and the atmosphere can be found. The authors aimed at making the users of the games aware of the environmental problems and to promote the right types of behaviour in the natural environment. For instance, the game WaterLife: Where Rivers Meet the Sea ${ }^{16}$ concerns the ecosystem of ocean estuary, the game Recycle City ${ }^{17}$ concerns sustainable development of a city, and participants of the game may learn how to segregate waste and reduce energy consumption. Next, the UCAR Center for Science Education $^{18}$ website offers a set of games related to weather, climate and atmosphere. A student using that type of games may understand the factors that shape weather and the way in which the climate changes. Issues related to weather and climate occur both in nature and geography curricula.

It is worth mentioning that a separate group of geography teaching aids, not discussed in the article, is

$14 \mathrm{http}: / /$ nationalgeographic.org/education/games-and-interactives/

$15 \mathrm{http}: / /$ games.noaa.gov

$16 \mathrm{http}: / /$ games.noaa.gov/oscar/welcome.htm

$17 \mathrm{https} / / / \mathrm{www} 3 . e p a . g o v /$ recyclecity/

$18 \mathrm{https} / / / \mathrm{scied}$.ucar.edu/games formed by interactive games and map applications related to Geographic Information Systems (GIS), to be used on PCs or mobile devices, including those that use the GPS to record the route travelled or mark visited points. The group may include also the so-called city games, like the game GIS \& Go promoted by ESRI and the game Pokémon Go, very popular in the summer of 2016.

\section{References}

Czepiżak A., Wądołowski M,. Metody aktywizujące w nauczaniu Zespół Edukacyjny w Trzebiatowie. Źródło: http://www.zet.edu. $\mathrm{pl} /$ sites/default/files/metody_aktywizujace.pdf

Hakan Tüzün H., Yılmaz-Soylu M., Karakus T., Inal Y., Kizılkaya G. (2009), The effects of computer games on primary school students achievement and motivation in geography learning. Computers \& Education, 1 (vol.52).

Kisiel, P. (2011). Komputerowe gry dydaktyczne w procesie nauczania. Dydaktyka informatyk, 6

Lange R., Osiecki J. (2014), Ogólnopolskie badanie „Nastolatki wobec Internetu" realizowane na zlecenie Rzecznika Praw Dziecka i NASK przez Pedagogium WSNS w okresie maj-czerwiec 2011r. Rzecznik Praw Dziecka, NASK (online, dostęp dn. 11.09.2016).

Lotherington H., Ronda N., S. (2009). Gaming geography: Educational games and literacy development in the Grade 4 classroom. Canadian Journal of Learning and Technology, 3 (vol. 35).

Morbitzer J. (2007). Edukacja wspierana komputerowo a humani styczne wartości pedagogiki. Wydawnictwo Naukowe Akademii Pedagogicznej.

Nodzyńska M., red. (2011). Metody motywacyjne w nauczaniu przedmiotów przyrodniczych. Zakład Chemii i Dydaktyki Chemii Uniwersytet Pedagogiczny im. Komisji Edukacji Narodowej, KRAwersytet Pedagogiczny im. Komisji Edukacji Narodowej, KRA-
KÓW, 2011. Żródło: http://uatacz.up.krakow.pl/ wwwchemia/ pliki/book3.pdf

Osiński Z. (2009). Polskie internetowe serwisy edukacyjne - czy służ edukacji?. e-mentor, 2 (29).

Papastergiou M. (2009). Digital Game-Based Learning in high school Computer Science education: Impact on educational effectiveness and student motivation. Computers \& Education, 1 (vol.52).

Pliszka M. (1997). Programy komputerowe użyteczne w nauczaniu i uczeniu się geografii. Geografia w szkole, 2.

Pokojska P. Pokojski W. (2012). Street view w serwisach Google możliwości wykorzystania w nauczaniu geografii. Geografia w szkole, 2.
Pokojska P. Pokojski W. (2015). Web mapping Google application in environmental educations. Edukacja Biologiczna i Środowiskowa, 1 (54).

Pokojski W. (2012). Technologia informacyjna i webGIS w ksztatceniu nauczycieli - kurs e-learningowy. e-mentor, 1 (43).

Rzeszewski M., Jasiewicz J. (2009), WebGIS - od map w internecie do geoprzetwarzania, [w:] Z. Zwoliński (red.), GIS - platforma inte gracyjna w geografi, Bogucki Wydawnictwo Naukowe.

Sysło M. M., (2009), E-learning w szkole. e-mentor, 1 (28). 